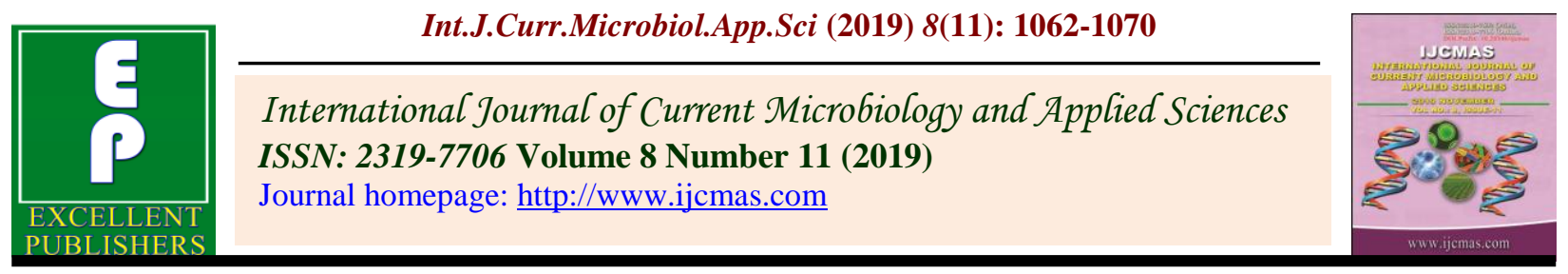

Review Article

https://doi.org/10.20546/ijcmas.2019.811.125

\title{
A Precise Approach for Fulfilling Protein and Amino Acids Requirement in Bovine: A Review
}

\author{
Manish Pandey ${ }^{1^{*}}$ and D.C. Patel ${ }^{2}$ \\ College of Veterinary Science and Animal Husbandry, Anand Agricultural University, \\ Anand-388001, India \\ *Corresponding author
}

\section{A B S T R A C T}

Keywords

fodder, Bovine,

Protein efficiency,

Daily milk yield,

Milk fat percentage,

Lactation yield

Article Info

Accepted:

10 October 2019

Available Online:

10 November 2019
The gap between demand and supply of feeds and fodder in India is huge, particularly for bovine (Cattle, Buffalo, Mithun and Yak). The total bovine population was 299.9 million (58.57 \% of total livestock) in 2012. The deficit of green and dry fodder was presented by Rathod and Dixit (2019) as 63.50 and $23.56 \%$, respectively in 2015 as per X five year plan which is projected to increase further by 2020 and 2025. Under present deficit condition of feed and fodder and future demands compel us to work on areas which are demand of present scenario. This review article underlines the importance of precision nutrition focusing particularly to protein and amino acids.

\section{Introduction}

India maintains around $11 \%$ of total world livestock in limited $2.3 \%$ of world geographical area, moreover for the last three decades the area under fodder production has remained stagnant, only $4-5 \%$ of total cultivated area (ICAR, 2016). Managing the feeds and fodder requirement of 512 million livestock including 300 million bovine therefore is crucial. Despite the huge gap between demand and supply of feeds and fodder, milk production has reached to 176.5 million ton (NDDB, 2018) and meat production has reached 7.4 million tons per annum (DAHD, 2017) respectively which present further scope for increase production if strategies like precision feeding are adopted.

Deficit of green and dry fodder in India was projected 64.21 and $24.81 \%$, respectively for 2020 (GOI-2002). High producing animals have higher requirement for dietary essential amino acids than supplied by the microbial protein alone (Ratika et al., 2018) and adequate supply of protein is crucial for performance of dairy animals. A Protein efficiency and imbalance of Amino Acids 
(AA) have a dramatic effect on growth, milk production and reproduction. Unscientific and imbalance feeding further complicating the present problem, it not only affects the utilization of nutrients but also maximize the ruminal fermentation losses there by increasing the wastage of nutrients into the environment (Chandrasekharaiah and Soren, 2018). Balanced feeding affects the cost of milk production, daily milk yield, milk fat percentage, lactation yield and nutrients required per liter of milk (NDDB, 2018). On account of shortage and to exploit milk production efficient utilization of available feed ingredient is need of hour.

\section{Protein availability and demand}

Concentrates in India provides around 8.5-9 million tones of total protein to dairy animals supporting production of only 0.45 million tonnes of milk protein (Tandon et al., 2008). The availability of protein meals annually in India was approximately 19-20 MMT, against a requirement of about 30-35 MMT. Out of available, approximately 4-5 MMT protein meals was exported, which further increases the gap between the requirement and the availability (Nilufar and Hossain, 2012).

\section{Protein requirement in ruminants}

Ruminants are unique in the way that their fore stomach has substantial number of beneficial microbes that can digest complex carbohydrates which others cannot. Hence they have protein requirement at 2 levels I. The nitrogen needs of rumen microbes and II.

\section{The protein need of the animal itself}

Dietary protein in them can be divided into two parts 1) Rumen Degradable Protein (RDP) and 2) Undegradable Dietary Protein (UDP). $\mathrm{RDP}$ is the part of the feed protein which degraded in rumen where as UDP is protein which escape (Bypass) the rumen fermentation gets digested in the abomasum and small intestine to supply AA (Dukes and Reece, 2004) (Table 1).

\section{Importance of maintaining RDP and RUP in Ration}

\section{Better utilization of protein resources}

Diet containing high RDP results in excess ammonia production more than capacity of rumen microbes to utilize, which after absorption through rumen epithilium converted into urea in liver, and excreted with urine. Ammonia emission from excreta can be reduced mainly by lowering the content of RDP (Van Duinkerken et al., 2005) (Fig. 1).

\section{Protection of protein meals}

Protein meal differ in rumen degradability. Some protein contain naturally available rumen bypass protein (30 to $40 \%$ of total CP) viz. cotton seed meal, toasted soybean, toasted groundnut meal, maize gluten etc. the cost of these ingredient is high. Whereas rapeseed meal, sunflower meal, Guar meal are available at cheaper rate but rumen by pass content in them is low.

Usually rumen protein degraded in the rumen to the extent $65-70 \%$ lead to wastage of nitrogen. These protein meals can be treated suitably so as to their degradability in the rumen from $70 \%$ to $30 \%$. Cost of treating protein meal is less than a rupee per $\mathrm{kg}$ and on feeding one $\mathrm{kg}$ treated meal in comparison to untreated, there is increase in milk production by more than one litre (Nilufar and Hossain, 2012).

Gulati et al., (2001) reported the change in rdp and rup fraction and amino acid availability at abomassu follwing formadihyde treatment of soyabean oil seeds RUP content increased from 20 to $80 \%$ and amino acids availability at abomasum increased by 4 times. 
Table.1 RDP and UDP content of common feed and fodder (Approx.)

\begin{tabular}{|c|c|c|c|c|}
\hline S.No & Feed/Fodder & CP\% & RDP\% & UDP\% \\
\hline $\mathbf{1 .}$ & Wheat grain & 10 & 75 & 25 \\
\hline $\mathbf{2 .}$ & Maize grain & 9 & 26 & 74 \\
\hline $\mathbf{3 .}$ & Bajra grain & 12 & 32 & 68 \\
\hline $\mathbf{4 .}$ & Jowar grain & 10 & 20 & 80 \\
\hline $\mathbf{5 .}$ & Oats grain & 10 & 84 & 16 \\
\hline $\mathbf{6 .}$ & Wheat bran & 16 & 73 & 27 \\
\hline $\mathbf{7 .}$ & Rice bran & 14 & 65 & 35 \\
\hline $\mathbf{8 .}$ & Ground nut cake & 42 & 77 & 23 \\
\hline $\mathbf{9}$ & Soyabean meal & 46 & 54 & 46 \\
\hline $\mathbf{1 0}$ & Rapeseed meal & 38 & 37 & 63 \\
\hline $\mathbf{1 1}$ & Sunflower meal & 30 & 47 & 53 \\
\hline $\mathbf{1 2}$ & Mustard cake & 35 & 75 & 25 \\
\hline $\mathbf{1 3}$ & Cotton seed cake & 35 & 51 & 49 \\
\hline $\mathbf{1 4}$ & Linseed cake & 28 & 58 & 42 \\
\hline $\mathbf{1 5}$ & Beseem green & 26 & 49 & 51 \\
\hline $\mathbf{1 6}$ & Lucerne fresh & 20 & 76 & 24 \\
\hline $\mathbf{1 7}$ & Oats grass & 13 & 51 & 49 \\
\hline $\mathbf{1 8}$ & Cowpea & 20 & 68 & 32 \\
\hline
\end{tabular}

(Source: NIANP, 2013)

Table.2 Nutrient profile of HCHO treated soybean oil seed

\begin{tabular}{|c|c|c|}
\hline Parameter & Unprotected ( g/kg) & Protected (g/kg) \\
\hline Total Protein & 285 & 285 \\
\hline Rumen Un-degradable Protein & $57(20 \%)$ & $228(80 \%)$ \\
\hline Amino Acids Available for Absorption at the Abomasum \\
\hline Methionine & 0.25 & 0.98 \\
\hline Lysine & 0.78 & 3.12 \\
\hline
\end{tabular}

(Gulati et al., 2001)

Table.3 Summary of bypass protein based feeding trial

\begin{tabular}{|c|c|c|c|c|c|}
\hline \multirow{2}{*}{$\begin{array}{c}\text { Feeding trial with } \\
\text { treated meal }\end{array}$} & Location & Milk (Lt.) & Fat\% & Protein \% & $\begin{array}{c}\text { Increase in comparision to control } \\
\text { (Rs/ani./day) }\end{array}$ \\
\cline { 3 - 6 } & & & & & 0.20 \\
\hline Sunflower meal in cows & Sarsa & 1.00 & 0.30 & 0.20 & 9.61 \\
\hline Rapeseed meal in cows & Ravipura & 1.10 & 0.20 & 0.20 & 8.60 \\
\hline Gaur meal in cows & Ravipura & 0.90 & 0.20 & 0.30 & 14.49 \\
\hline $\begin{array}{c}\text { Sunflower meal in } \\
\text { Buffalo }\end{array}$ & Chikhodra & 0.80 & 0.40 & & 5.80 \\
\hline $\begin{array}{c}\text { Rapeseed meal in low } \\
\text { yielding cows }\end{array}$ & Sarsa & 0.70 & 0.20 & 0.20 & \\
\hline
\end{tabular}

(NDDB, 2006) 
Table.4 Lys and Met values for common feeds

\begin{tabular}{|c|c|c|}
\hline Particulars & Lys $(\%$ of CP) & Met (\% of CP) \\
\hline Corn silage & 2.5 & 1.5 \\
\hline Oats & 4.2 & 2.9 \\
\hline Wheat & 2.8 & 1.6 \\
\hline Linseed meal & 3.7 & 1.8 \\
\hline Soybean meal & 6.3 & 1.4 \\
\hline Rice bran & 4.4 & 2.06 \\
\hline Wheat bran & 4.01 & 1.44 \\
\hline Feather meal & 2.32 & 0.68 \\
\hline Fish meal & 6.84 & 2.50 \\
\hline Meat meal by product & 4.90 & 1.30 \\
\hline Poultry by product meal & 5.06 & 1.58 \\
\hline
\end{tabular}

(NRC, 2001)

Fig.1 Fate of rumen degradable protein (RDP) and rumen undegradable protein (RUP)

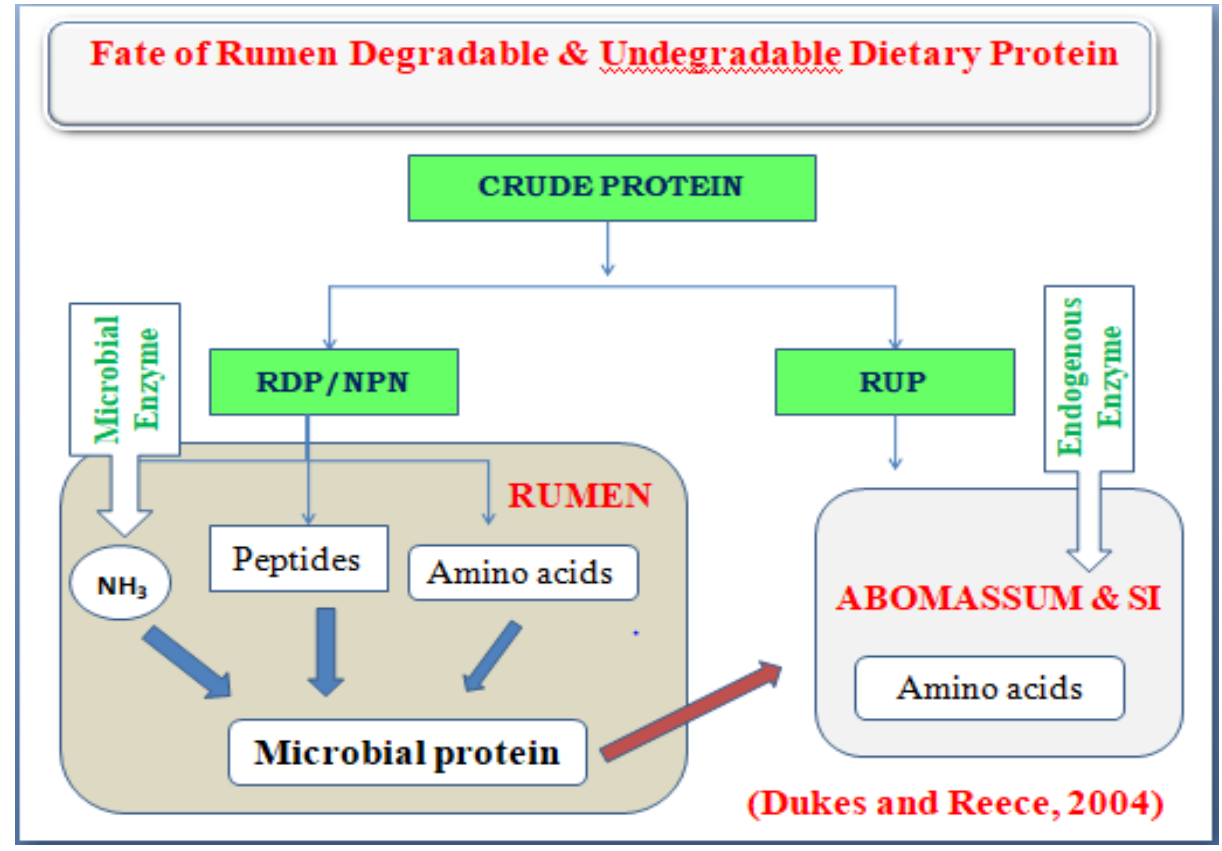

How to fed bypass protein supplement and economic benefits

Treated protein meal can be used as top feed or directly at rate of $1 \mathrm{~kg}$ per animal per day or else treated meal can be incorporated in cattle feed and this feed can be given at the rate 3 to $4 \mathrm{~kg}$ per animal as per the production. The cost of feed ranges from 70 to 80 paisa per $\mathrm{kg}$ only and result in increase milk production, SNF and Fat\% (NDDB, 2006) (Table 2 and 3).

\section{Effect of feeding varying RDP and RUP ratio in bovine ration}

Replacement of $10 \%$ crude protein $(\mathrm{CP})$ from soya bypass protein resulted in average daily gain and cost of feeding for per $\mathrm{kg}$ weight gain 
also reduced when bypass feeding was done in heifers (Kumari et al., (2016). Lactating cows fed $8 \%$ RDP and 6\% RUP in the diet, minimizes dietary nitrogen input and nitrogen output to the environment without compromising milk production reported by Kaufman (2016). Feeding of concentrate mixture containing formaldehyde treated oil cakes of rapeseed and cottonseeds economically improved yield of milk and its components. Furthermore, the treatment effects were more pronounced during early lactation (Aasiwal et al., 2015). Arewad et al., (2010) reported calves which were fed concentrate with formaldehyde treated bypass protein source showed significant increase in average daily weight gain and the feed conversion efficiency also improved significantly. Cost of feeding for per $\mathrm{kg} \mathrm{wt}$ gain also reduced by Rs. 3.69 in calves fed with bypass protein source.Buffaloes which were fed with ration having RDP:RUP in ration as 50:50 showed significant increase in milk yield and the urinary nitrogen loss was also lowest. Days open also reduced to 99 and conception rate inceased to $75 \%$ by maintain RDP:RUP of 50:50 (Mahr-Un-Nisa et al., 2008)

\section{Ideal balance of absorbed amino acids}

Amino acids composition of each protein is different, key regulators of various physiological processes such as milk production, growth, reproduction and immunity (Schwab, 2012).

Rulquin et al., (1993) used an indirect nutrient-response approach to establish the concentrations of Lysine (Lys) and Methionine (Met) that are needed in Metabolozable Protein (MP) to maximize milk protein yield lactating cow. They reported ideal Lys and Met percentage in MP should be 7.2 and $2.4 \%$, respectively ratio (3:1). Later (NRC, 2001) and Doepel et al., (2004) also reported similar values for ideal concentration of Lys amd Met in metabolizable protein for maximum milk yield which were similar with the concentrations of Lys and Met in Protein content of milk, lean tissue and rumen bacteria reported by (O'Connor et al., 1993). later in 2009 White house and Schwab reported the similar values for concentration of Met and Lys in MP and ideal Lys to Met ratio as 3:1 form maximum content of milk protein.

Plant protein and animal proteins have different AA composition with former are deficient in Lys and Met (NRC, 2001).

Among AA, the availability of Met and Lys in MP across a wide range of feed ingredients for bovine is low, hence, limiting its use for mammary and liver metabolism (Osorio, 2018).

\section{Effect of supplementation of rumen protected Met and Lys on bovine}

Abdelmegeid et al., (2018) supplemented the diet with Rumen-Protected Met at the rate $(0.08 \%$ of DMI) during peripartal period and studied its effect on abundance of major species of rumen bacteria. The dry matter intake increased significantly due to supplementation and did not compromise growth of major bacterial species in the rumen. In fact, had a positive effect on three major species (Table 4). Gavade et al., (2019) reported calves which were fed with $3 \mathrm{~g}$ rumen protected Met and $20 \mathrm{~g}$ rumen protected_Lys had highly significant increase in average fortnight gain in weight and significant increase in average daily gain in weight. Feeding cost for per $\mathrm{kg}$ weight gain also reduced in calves supplemented with rumen protected Met and Lys. Feed conversion efficiency of Murrah buffalo heifers due to supplementation of commercial bypass AAs. was also improved significantly (Kumar et al., 2018. Feed conversion ratio 
(FCR) was lowest in heifers which were supplemented with $2 \mathrm{~g} / \mathrm{d}$ of RPM $+10 \mathrm{~g} / \mathrm{d}$ of RPL (Singh et al., 2015). Supplementation of bypass Met and Lys at the rate of $5 \mathrm{~g}$ and 10 $\mathrm{g} /$ day resulted in significant increased in daily weight gain and feed conversion ration also reduced when heifers were supplemented with bypass Met and Lys. Cost of feeding per animal per day was significantly higher; when diet was supplemented with bypass Met and Lys but cost of feeding for per kg weight gain reduced due to supplementation (Movaliya, 2013).

The milk yield and protein yield was increased significantly only when diet was supplemented with both rumen-protected Met and Lys (Awawdeh, 2016). Ahmed et al., (2016) studied effect of supplementation of Rumen Protected Lys and Met on production performance in early lactating Nili-Ravi buffaloes. Buffaloes which were provided with $40 \mathrm{gm}$ rumen protected Lys and $14 \mathrm{gm}$ rumen protected Met and 30gm rumen protected Lys and $10 \mathrm{gm}$ rumen protected Met, respectively showed significant increase in milk production. Supplementing rumen protected lysine from 4 wk prepartum improves performance. Milk yield and protein yield increased significantly during fresh and high production period (Batistel et al., 2017). Supplementation of rumen- protected Met at the rate of $0.034 \%$ on dry matter basis did not improve milk yield, fat $\%$ and protein $\%$ but incidence of mastitis was lower when diet supplemented with rumen- protected Met was fed (Tamura et al., 2019). Supplementation of Met to make Lys: Met near to 3:1. Milk yield, fat $\%$ and protein $\%$ was comparable between the groups but feeding ration with lysine and met ratio nearly 3:1 showed higher pregnancy rate (Toledo et al., 2017).

A study was conducted at Werner Meyer GbR farm in North-West Germany by Kemin feed company to see the effect of top supplementation of rumen bypass lysine on performance of milk yield along with reproductive behavior supplementation of rumen bypass lysine at the rate of $25 \mathrm{gm}$ increased energy corrected milk by $1.3 \mathrm{~kg}$ and open days reduced to 97 and service per conception also reduced to 1.9 (Kemin, 2017). Pregnancy rate of heifers which received $14 \%$ $\mathrm{CP}$ and $25 \mathrm{gm}$ protected Met was comparable with heifers receiving $16 \% \mathrm{cp}$ and $15 \mathrm{gm}$ protected Met (Titi et al., 2013).

There is a huge gap between demand and supply of feed and fodder to bovine, and increasing population of high productive animal, adding complexity to this problem.

The RUP and RDP fraction and composition of amino acids in protein is more important than CP content for growth, production and reproduction. Feeding excess RDP results in more nitrogen loss, wastage of nutrients therefore intelligent selection feed ingredient and using treated protein meal and optimal RDP and RUP ratio in very important. UDP level can be increased to $50 \%$ in high producing animals during early lactation.

Feeding bypass protein is more beneficial in terms growth and more economical for calf and heifers. The availability of Met and Lys in plant proteins is low therefore supplementation of Met and Lys is essential. Optimal amount of Lys and Met is 7.5 and 2.5 $\%$, respectively in MP (ratio be 3:1). Average daily weight gain, milk production, milk fat and protein, fertility, conception rate and immunity increases by adding 2 to $50 \mathrm{~g}$ of rumen protected Met and Lys.

\section{Future prospect}

Research is needed to improve diet formulation models to balance for amino acid requirements as well as RDP: RUP Quantify the potential to reduce protein feeding when 
using protected amino acids, thereby reducing the wastage and excretion of nitrogen in to the environment.

\section{References}

Aasiwal, D. P., Meena, B. S., Mahesh, M. S., Sharma, K., and Lalremuta, C. 2015. Effect of feeding formaldehyde treated rapeseed and cottonseed cakes on milk yield and composition at various stages of lactation and parity in Jersey cows. Journal of Animal Research, 5(1), 15.

Abbasi, I. H. R., Abbasi, F., El-Hack, M. E. A., Abdel-Latif, M. A., Soomro, R. N., Hayat, K., Mohamed, M. A., Bodinga, B. M., Yao, J., and Cao, Y. 2018. Critical analysis of excessive utilization of crude protein in ruminants ration: impact on environmental ecosystem and opportunities of supplementation of limiting amino acids - a review. Environmental Science and Pollution Research, 25(1), 181-190.

Abdelmegeid, M. K., Elolimy, A. A., Zhou, Z., Lopreiato, V., McCann, J. C., and Loor, J. J. 2018. Rumen-protected methionine during the peripartal period in dairy cows and its effects on abundance of major species of ruminal bacteria. Journal of animal science and biotechnology, 9(1), 17.

Ahmed, S., Gohar, M., Khalique, A., Ahmad, N., Shahzad, F., Rahman, A., and Khan, M. I. 2016. Effect of Supplementation of Rumen Protected Lysine and Methionine on Production Performance, Milk and Blood Parameters of Early Lactating Nili-Ravi Buffaloes. Pakistan Journal of Zoology, 48(2).

Arewad, G.R. 2010. Study on Effect of Feeding Bypass Protein based Total Mixed Ration on Performance of Growing Crossbred Calves. (M.V.Sc thesis, Anand Agricultural University, Anand Gujarat. Retrieved from http://krishikosh.egranth.ac.in/displaybit stream?handle $=1 / 5810012924$.
Awawdeh, M. S. 2016. Rumen-protected methionine and lysine: effects on milk production and plasma amino acids of dairy cows with reference to metabolisable protein status. Journal of Dairy Research, 83(2), 151-155.

Batistel, F., Arroyo, J. M., Bellingeri, A., Wang, L., Saremi, B., Parys, C. and Loor, J. J. 2017. Ethyl-cellulose rumen-protected methionine enhances performance during the periparturient period and early lactation in Holstein dairy cows. Journal of dairy science, 100(9), 74557467.

Chandrasekharaiah, M., and Soren, N. M. 2018. Precision Nutrition with Particular Reference to Protein and Amino Acids for Enhancing the Productivity in Ruminants. E- Compendium ICAR sponsored short course on Recent Advances in Nutritional-Physiological Approaches for Improving Reproduction and Production in Livestock Under Climate Change Scenario. ICARNIANP, Bengaluru, India.

Department of Animal Husbandry and Dairying. 2017. Annual Report-2016-17. Ministry of Agriculture and Farmers Welfare Government of India.

Doepel, L., Pacheco, D., Kennelly, J. J., Hanigan, M. D., Lopez, I. F., and Lapierre, H. 2004. Milk protein synthesis as a function of amino acid supply. Journal of Dairy Science, 87(5), 1279-1297.

Dukes, H. H., and Reece, W. O. 2004. Dukes Physiology of Domestic Animals. Ithaca, NY, comstock Pub.

Gavade, V. S., Gadegaonkar, G. M., Ramteke, B. N., Pagdhuneand, A. G., and Kanduri, A. B. 2019. Effect of Supplementation of Rumen Protected Methionine and Lysine in Crossbred Calves. International Journal of Livestock Research, 9(4), 182-188. doi: 10.5455/ijlr.20181223054332..

Government of India 2002. Tenth Five Year Plan, Planning Commission. India: Government of India. 
Gulati et al., 2001. Cited from Tandon, M., Siddique, R. A., and Ambwani, T. (2008). Role of bypass proteins in ruminant production. Dairy Planner, 4(10), 11-14.

Indian Council of Agriculture Research. 2016. Handbook of Animal Husbandry. Forth Revised Edition. New Delhi, India.

Kaasik, A., Ots, M., and Leming, R. 2009. Relationship Between the Content of Rumen Degradable Protein in Dairy Cow Diets and Emission of Excreted Ammonia Nitrogen. Veterinarija ir Zootechnika, 47(69).

Kaufman, J.D. 2016. Effect of Varying Rumen Degradable and Undegradable Protein on Milk Production and Nitrogen Efficiency in Lactating Dairy Cows under Summer Conditions. (Master's Thesis, University of Tennessee, Knoxville. Retrieved from

Kemin. (2017, September 10). Expect more with lysine supplementation. Retrieved from https://www.allaboutfeed.net/FeedAdditives/Partner/2017/9/Expect-morewith-lysine-supplementation-183204E/.

Kumar, R., Kar, D., Singh, V., Ramkaran, Sihag, S., Gulati, H.K., and Sahu, S. 2018. Feed Conversion Efficiency of Murrah Buffalo Heifers Due to Supplementation of Commercial Bypass Amino Acids and Fish Meal, Int. J. Pure App. Biosci. 6(2): 264-271. doi: http://dx.doi.org/10.18782/23207051.62 78.

Kumari, A., Kar, D., Gulati, H. K., Akbar, M. A., Sihag, S., Kumar, S., and Chhikara, S. K. 2017. Influence of feeding different sources of bypass protein on growth performance, hematology and economics in Murrah buffalo heifers. Indian Journal of Animal Research, 51(4).

Mahr un Nisa, A., Javaid, A., Shahzad, M.A., and M. Sarwar. 2008. Influence of Varying Ruminally Degradable to Undegradable Protein Ratio on Nutrient Intake, Milk Yield, Nitrogen Balance, Conception Rate and Days Open in
Early Lactating Nili-Ravi Buffaloes (Bubalus bubalis). Asian-Aust. J. Anim. Sci., 21(9), 1303 - 1311.

Movaliya, J. 2013. Effect of Rumen Bypass Met. and Lys. Supplementation on Performance of Jaffarabadi Heifers. (M.V.Sc. Thesis, Anand Agricultural University, Anand, Gujarat).

National Dairy Development Board. 2018. Annual Report, 2017-18. Anand, Gujarat, India. Reterived from https://www.nddb.coop/sites/default/file S/NDDB_AR_201718_\%28Eng\%29.pdf.

National Dairy Development Board. 2006. Bypass protein supplement. Retrieved from

National Institute of Animal Nutrition and Physiology 2013. Nutrients Requirement of Animals-Indian Feeds and Fodder. ICAR-NIANP, Bengaluru, India.

National Research Council. 1989. Nutrient Requirements of Dairy Cattle. Natl. Acad. Press, Washington, DC.

National Research Council. 2001. Nutrient Requirements of Dairy Cattle. Vol. 7th. Natl. Acad. Press, Washington, DC.

Haque and Hosaain, S. A. 2012. Concept of Bypass Protein feeding in Ruminants. Livestock Line, 5(11), 9-13.

Osorio, J. S. 2018. Amino acid balancing and its role on metabolism, inflammation, and oxidative stress: Future molecular implications. Retrieved from

Rathod, P., and Dixit, S. 2019. Green fodder production: A manual for field functionaries. International Crops Research Institute for the Semi-Arid Tropics. Patancheru, Telangana, India, 56.

Ratika, K., Singh, R. K. J., and Dahiya, S. S. 2018. Methionine, Lysine and Choline in Dairy Cows: a Review Article. Int. J. Curr. Microbiol. App. Sci. 7(07): 39213934. doi: https://doi.org/10.20546/ ijcmas.2018.707.456

Rulquin, H., Vérité, R., Guinard-Flament, J., and Pisulewski, P. M. 2001. Acides amines digestibles dans l'intestin. Origines des 
variations chez les ruminants et répercussions sur les protéines du lait. Productions Animals, 3 (14), 201-210).

Schwab, C. 2012. The principles of balancing diets for amino acids and their impact on $\mathrm{N}$ utilization efficiency. In Proceedings of the 23rd Ruminant Nutrition Symposium. University of Florida, Gainsville, Florida. (1-15).

Singh, J. K., Roy, D., Kumar, V., Kumar, M., and Sirohi, R. 2015. Effect of supplementing rumen protected methionine and lysine on nutrient intake and growth performance of Hariana heifers. Indian Journal of Dairy Science, 68(6).

Sylvia, S. (2014, July 15). NH DES Releases Great Bay Nitrogen Non-Point Source Study Final Report. Strafford Region Plans.

Tamura, T., Inoue, K., Nishiki, H., Sakata, M., Seki, M., Koga, T., Ookubo, Y., Akutsu, K., Sato, S., Saitou, K., and Shinohara, H., 2019. Effects of rumen- protected methionine on milk production in early lactation dairy cattle fed with a diet containing $14.5 \%$ crude protein. Animal Science Journal, 90(1), 62-70.

Tandon, M., Siddique, R. A., and Ambwani, T. 2008. Role of bypass proteins in ruminant production. Dairy Planner, 4(10), 11-14.

Titi, H. H., Azzam, S. I., and Alnimer, M. A.
2013. Effect of protected methionine supplementation on milk production and reproduction in first calf heifers. Archives Animal Breeding, 56(1), 225236.

Toledo, M.Z., Baez, G.M., Garcia-Guerra, A., Lobos, N.E., Guenther, J.N., and Trevisol, E. 2017. Effect of feedingrumen-protected methionine on productiveand reproductive performance of dairy cows. PLOS ONE. 12(12). doi. org/10.1371/journal.pone.0189117.

Tyler, C. 1956. The development of feeding standards for livestock. Agric. Hist. Rev, 4(2), 97-107. Retrived from https://www.bahs.org.uk/AGHR/ARTIC LES/04n2a3.pdf.

Van Duinkerken, G., André, G., Smits, M. C. J., Monteny, G. J., and Šebek, L. B. J. 2005. Effect of rumen-degradable protein balance and forage type on bulk milk urea concentration and emission of ammonia from dairy cow houses. Journal of Dairy science, 88(3), 10991112.

Walli, T. K., and Sirohi, S. K. 2004. Evaluation of heat treated (roasted) soybean on lactating cross breed cows. Project Report of the Collaborative Project between National Dairy Research. Research Institute, Karnal and American Soybean Association. New Delhi.

\section{How to cite this article:}

Manish Pandey and Patel, D.C. 2019. A Precise Approach for Fulfilling Protein and Amino Acids Requirement In Bovine: A Review. Int.J.Curr.Microbiol.App.Sci. 8(11): 1062-1070. doi: https://doi.org/10.20546/ijcmas.2019.811.125 